\title{
Teaching and learning English vocabulary in a Spanish context
}

Andreea Stefanescu al310593@uji.es 


\section{Abstract}

\section{(Abstract}

Although the problem of teaching and learning vocabulary has experienced a great development in the last decades, in the contemporary context, teaching vocabulary knowledge is still a major challenge on all levels. The present article attempts to tackle and solve some of the issues encountered by both teachers and students in the classroom regarding vocabulary knowledge. This article presents a study examining the effects of the Vocabulary Box, Kick Me Activity, and the Vocabulary Survey in $2^{\text {nd }}$-year $\mathrm{ESO}^{1}$ students, to show if the method of learning words has an impact on the student learning process. Results are based on the final written test, student observation, and student survey. Different methods produced significant variations in achievement scores, and the data-collection instruments showed that students had a preference for the Vocabulary Box and selected the Kick Me Activity as a second choice. This empirical study produces findings linked to the interaction of students with different dynamic and stimulating tasks that encourage not only participation, fun and engagement, but also vocabulary knowledge acquisition.

Keywords: English vocabulary, Spanish context, learning.

\section{Introduction}

The end of the last millennium has seen a resurgence of interest in the teaching of foreign languages and, in particular, vocabulary. Societal changes and the progress of modern science are reflected primarily and directly through vocabulary. This research presents several questions that need to be addressed when thinking about teaching and learning English vocabulary: Why is it important to teach vocabulary? What is the best way to teach vocabulary? What kind of tools can teachers implement in teaching vocabulary?

\section{Objectives}

The main objective of this article is to identify students' perceptions on vocabulary using a survey (table 1). The second objective is to implement new, dynamic and interactive tools for teaching English vocabulary in a Spanish context. These vocabulary tools are intended to help build communication and interaction in the classroom. A specific objective of this research is to assess their

\footnotetext{
${ }^{1}$ Compulsory Secondary Education
} 
efficiency and, also, to look for alternatives, in case they do not achieve the target.

\section{Material and method}

An eminently practical and dynamic methodology is applied to pre-reading and post-reading stages. Students, as protagonists in the construction of their vocabulary learning, must participate actively and cooperatively in order to facilitate meaningful learning in coexistence with others. The methodological strategies used will be: the Vocabulary Box game as an icebreaker and the Kick Me Activity as the post-reading activity.

Each of the necessary materials and didactic resources to carry out the activities programmed throughout the vocabulary games are shown. Classroom requirements as well as the necessary material are detailed.

\begin{tabular}{ll}
\hline $\begin{array}{l}\text { Classroom } \\
\text { requirements: }\end{array}$ & $\begin{array}{l}\text { language laboratory with good acoustic conditions, } \\
\text { computer and internet connection, blackboard, } \\
\text { projector and projection screen. }\end{array}$ \\
\hline $\begin{array}{l}\text { Materials required } \\
\text { by the students: }\end{array}$ & pens, paper, handouts \\
$\begin{array}{l}\text { Methodological } \\
\text { aspects: }\end{array}$ & $\begin{array}{l}\text { communicative approach, cooperative learning and } \\
\text { interaction }\end{array}$ \\
\hline
\end{tabular}

\section{Vocabulary Survey}

To begin with, a structured survey was undertaken to identify what students thought about learning English vocabulary in general. In order to collect evidence from many students, a survey tool was created (Table 1). A relatively large sample group of 79 students was gathered to provide a range of results. The survey was conducted in IES Bovalar with $75 \%$ students who speak Spanish as L1, and $25 \%$ students who are immigrants. This questionnaire sought to identify what students think about English Vocabulary in general, and how it can be learned in a Spanish high school context. 


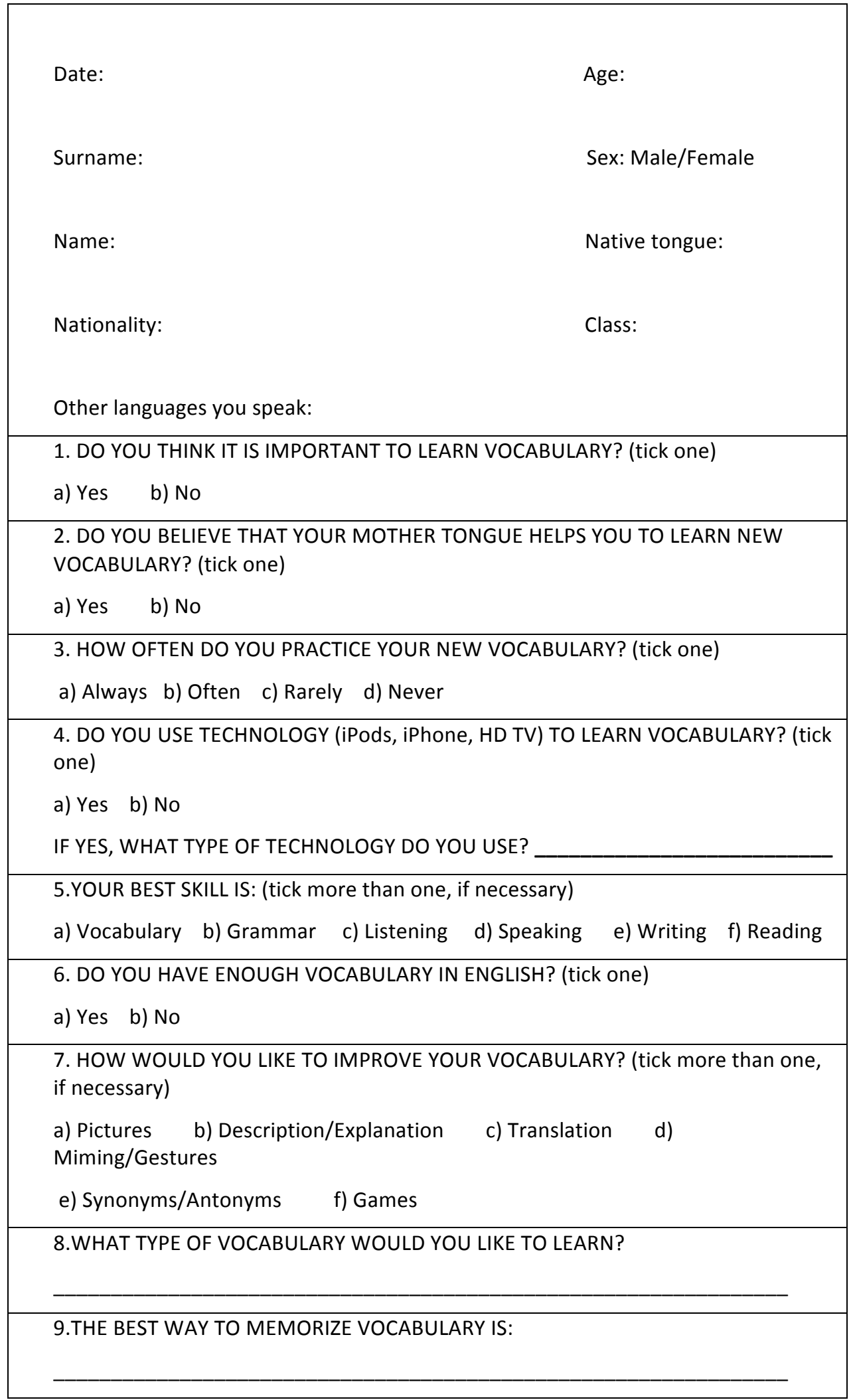

The assumption was made that students from different levels ( 2 $\mathrm{ESO}^{2}, 4 \mathrm{ESO}$, and 1 BACHILLERATO) would together constitute a

\footnotetext{
${ }^{2}$ Compulsory Secondary Education
} 
representative sample of pupils as a whole. The study was carried out in the following period: $27 / 04 / 2015-30 / 04 / 2015$. The groups that were investigated included boys and girls between the ages of 13-18. Therefore, the survey provided data on general vocabulary knowledge and acquisition. We have chosen only a few questions from the Survey to analyse those that we considered as more relevant to our research:

Table 2. Students percentage on some relevant questions

\begin{tabular}{|l|l|}
\hline \multicolumn{1}{|c|}{ Survey Questions } & \multicolumn{1}{|c|}{ Student percentage } \\
\hline $\begin{array}{l}\text { 1. Do you think it is important } \\
\text { to learn vocabulary? }\end{array}$ & $\begin{array}{l}\text { YES: } 99 \% \\
\text { NO: } 1 \%\end{array}$ \\
\hline $\begin{array}{l}\text { 2. Do you believe that your } \\
\text { mother tongue helps you to } \\
\text { learn new vocabulary? }\end{array}$ & $\begin{array}{l}\text { YES: } 59 \% \\
\text { NO: } 41 \%\end{array}$ \\
\hline $\begin{array}{l}\text { 4. Do you use technology (iPods, } \\
\text { iPhone, HD TV) to learn vocabulary? } \\
\text { (tick one) }\end{array}$ & YES: $71 \%$ \\
\hline $\begin{array}{l}\text { 6. Do } 29 \% \\
\text { vocabulary in English? }\end{array}$ & YES: $52 \%$ \\
\hline
\end{tabular}

Regarding the first question, the acquisition of vocabulary in language learning is as essential as numbers are in mathematics. Furthermore, looking at the percentage rate ( $99 \%$ for yes), it is evident that the relevance of vocabulary for pupils is very high. Moreover, the effort of the teachers to cultivate in students a taste for new vocabulary is greater, and it is reflected in the survey answers that students are aware of the importance of learning new vocabulary.

Regarding the second question on the survey, Schmitt and McCarthy stated that: "recent research has confirmed more and more strongly what language teachers have always known: that the mother tongue has a considerable influence on how the second language is learnt and used» $(1997,160)$. Therefore, the influence of the mother tongue is very important when learning vocabulary in another language, as Schmitt and McCarthy state: "the mother tongue can influence the way second-language vocabulary is learnt, the way it is recalled for use, and the way learners compensate for lack of knowledge by attempting to construct complex lexical items». (1997, 179).

The fourth question highlights that vocabulary knowledge is acquired with the help of new technology, such as computers, iPhones, iPads and iPods. The findings in Table 2 show that a majority 
of students (71\%) use electronic devices to learn new vocabulary; however, only $29 \%$ of students prefer other materials to improve their vocabulary. Electronic devices brought a vast range of possibilities to the educational plan, particularly in the field of learning vocabulary. Some of the benefits of those devices are to give students instant feedback, portability, and fun. Therefore, using electronic devices is a convenient way for students to practice and learn new vocabulary.

Finally, the sixth question explores the students' opinion regarding the amount of English vocabulary that they possess. Some of them were optimistic by saying "yes", they had a wide range of vocabulary, while others seemed more realistic and responded with a «no».

Table 3. Students percentage on question seven from the Survey

\begin{tabular}{|l|l|}
\hline Survey Questions & \\
& Multiple responses \\
\hline 7. HOW WOULD YOU LIKE TO & a) Pictures: $35 \%$ \\
IMPROVE YOUR VOCABULARY? & b) Description/Explanation: $14 \%$ \\
(tick more than one, if necessary) & $\begin{array}{l}\text { c) Translation: } 39 \% \\
\text { d) Miming/Gestures: } 14 \%\end{array}$ \\
& $\begin{array}{l}\text { e) Synonyms/Antonyms: } 8 \% \\
\text { f) Games: } 56 \%\end{array}$ \\
\hline
\end{tabular}

When it comes to the strategies column, the results in Table 3 show that more than half of the respondents -56 out of 79 students - think they can improve their English vocabulary with the help of games. This can, at least partially, be attributable to the study style encouraged by their English teacher, Alicia Garcia Martí, who implemented different games and strategies that foster the students' motivation.

As for the use of translation and pictures, it was found that a considerable number of students -39 and 35 subjects - try to use them to enhance the new vocabulary. The least preferred strategy to improve vocabulary was through synonyms and antonyms, to which only 8 students responded.

Hence, results in Table 3 show that students seem to prefer learning vocabulary through games and translation. Knowing the famous proverb that "A picture is worth thousand words", teachers should consider and apply this reflection in their teaching. However, it should be indicated that, from the perspective of students, very important causes that lead to learning new vocabulary are linked to both teachers and the students' performance.

In conclusion, it is important to mention that the present survey has identified and contributed to the discovery of the opinions and 
attitudes towards vocabulary knowledge in a Spanish context. We can conclude that these are all strategies which students already use and regard as beneficial. The fact that students prefer games leads us to the next step.

\section{Games}

Society is in the process of developing communication, of enriching vocabulary with new words. Humans invented crosswords, scrabble, etc.; hence, we can say that words have become a type of "toy» for individuals. People use them whenever and however they want. Unlike traditional methods of teaching foreign language vocabulary, modern methods involve interactivity and a direct participation of those trained in the teaching-learning process. One of the most useful interactive methods for learning a modern language and, particularly new vocabulary, is the incorporation of games: "to memory and performance benefits, games and interactive learning methods have important social benefits for students. These activities allow students to practice using the vocabulary of the discipline» (Kumar Rita and Robin Lightner 2007).

Before explaining the impact of games in teaching vocabulary, it is relevant to clarify the meaning of the word game. According to the Oxford Dictionary, the concept game means: "a form of competitive activity or sport played according to rules». The present section focuses on a number of advantages that students can experience with games while also learning new vocabulary.

As mentioned above, games have multiple advantages for students, especially when they learn new vocabulary in English. Firstly, games have the effect of motivating pupils. In this respect, Ali Sorayaie indicated that: "games can lower anxiety, thus making the acquisition of input more likely. They are highly motivating and entertaining, and they can give shy students more opportunity to express their opinion and feelings» $(2012,253)$. Therefore, games have the power of motivating and challenging students in an exciting manner, and sometimes even the timidest students feel free and relaxed (this happened during our research).

Secondly, Byrne points out that games can be performed at all stages of learning, by reviewing and acquiring new vocabulary:

The maximum benefit can only be obtained from language games if they form an integral part of the programme, at both the practice and the production stages of learning. Used in this way, they provide new and interesting contexts for practicing language already learnt- and often for acquiring new language in the process $(1976,99)$. 
Thirdly, according to Harmer, games are one of the teacher's tools that can lead to the assimilation of words much easier, creating a relaxed learning environment:

Games are a vital part of a teacher's equipment, not only for the language practice they provide, but also for the therapeutic effect they have. They can be used at any stage of a class to provide an amusing and challenging respite from other classrooms activity, and are especially useful at the end of a long day to send the students away feeling cheerful about their English class $(1983,94)$.

In the same line, Thornbury states that: "useful games are those that encourage learners to recall words and, preferably, at speed» (2002, 102).

Another aspect that must be mentioned in this section is that the teaching of games at high-school level is different from primary one. Although it seems harder to involve students in these activities, they are interested, as it breaks down the barriers and represents a deviation from their usual class activities. In this case the didactic game can be used to, either start a discussion, in order to «break the ice», to highlight competitive features of participants, or to review some concepts studied.

However, if the games are not well explained by the teacher, they cannot be played well and achieve the proposed goals. In this regard, Thanh Huyen and Thu Nga declare that: "games cannot be successful if the teacher does not explain the tasks and roles of students clearly in playing games» $(2003,12)$.

Many researches argue that games have a powerful impact on students; however, teachers must take into consideration different aspects when they implement games in the class. For instance, Thornbury states that: «many word games deal solely with isolated rather than contextualized- words, and often require only shallow processing on the part of the learner, they should be used judiciously» $(2002,102)$. Thus, efficiency depends on the game and what it actually fosters in a class.

To meet the specific objective, we tried to implement two types of vocabulary games, in order to gain information regarding the students' satisfaction and acquisition of new vocabulary. Below we will list two types of games and when they can be used as part of a lesson. Games can be used at the beginning of the class, in the middle and at the end. 


\section{Procedure}

This game can be used for all levels and ages. The game should last no longer than five to ten minutes. This warm-up game can be applied at the beginning of a class. The teacher asks every student to pick a word from the box and then translate it into Spanish. At the end of the class, the teacher provides students with a piece of paper onto which they write their newly acquired word which they then put it into their so-called "Vocabulary Box».

We did this activity for a month during my internship at IES Bovalar at the beginning and the end of our classes with the three different groups that we taught. What we found interesting was the fact that one student wrote the same word five times on the piece of paper to, perhaps, retain the word, whereas another student returned a blank piece of paper, arguing that he had not learnt anything in the lesson. However, what really surprised us was the students' attitude towards this activity. One day when we forgot to offer them the game, they reminded us by saying: "When are we doing the Vocabulary Box?». This activity can be used as a warm-up to check what students remember from the previous lesson.

Therefore, we can say that the Vocabulary Box is a type of "Pandora's box», as it arouses students' curiosity, mixed with other feelings such as: anticipation, joy, intuition, and creativity. In the last class with our students, we wanted to surprise and reward them for their participation, interest, enthusiasm, and for creating a good atmosphere, by putting sweets into the Vocabulary Box instead of words. We wanted to thank them in a special way as the experience had been very rewarding for us.

\section{Study case of the «Kick me Activity»}

\section{Methodology and Procedures Participants of the "Kick me Activity»}

This game can be implemented at all levels and at any age. As this research was based on a specific task called "Kick Me Activity", we chose three different classes of the same level (A B; C, E; and D), in IES Bovalar, Castelló de la Plana, Spain. There were 43 students between the ages of 11 and 15, and their level of English can be classified from elementary to intermediate.

The three groups were chosen because we considered the task adequate for their level. Moreover, they were some of the groups that had been taught by their tutor. For this reason, it can be said that they had almost the same level and interests. 
The first group ( $2^{\text {nd }}$ ESO A, B) consisted of 16 students. When we introduced the activity, there were only 10 students ( 6 boys and 4 girls). The tutor commented that in this course the students had a lower level of English than in the other two groups. Students gave the impression that they were not very interested in English. The second group ( $2^{\text {nd }}$ ESO C, E) was made up of 15 students; however, only 12 students ( 2 boys and 10 girls) were present on the day we performed the task. Even though this class had more reluctant students regarding the subject, it worked better than with the first group, as they enjoyed doing the task.

The third group ( $2^{\text {nd }}$ ESO D) consisted of 20 students with 17 students (11 boys and 6 girls) present on the day of the activity. Despite being a larger group $t$, the expectation was higher, as their level of English was better and their interests very well defined. Most of the students tried their best using English as their vehicular language during this activity. Furthermore, their tutor mentioned that this group was more responsible and engaged in the English Subject.

The objectives of the Kick Me Activity are: this game is used in the post-reading stage, to learn new vocabulary, students have to match the words with their exact definition and it can be implemented in any subject. The Kick Me activity was developed in the post-reading stage, and it encourages movement in the class, increasing focus, engagement, and retention of information. The teacher gives the students a handout where there are some definitions on the right side of the paper, and they have to find the missing words on the left side for those definitions (Table 4.). Therefore, students have to find the answers to blanks on the worksheet by looking at the words that the teacher put on the students' backs, using labels. As a result, throughout this activity, students learn the new vocabulary that is going to be in the text. In this way, during the while-reading stage, they know the meaning of the new words that appear in the text. 
Table 4. Student's Handout

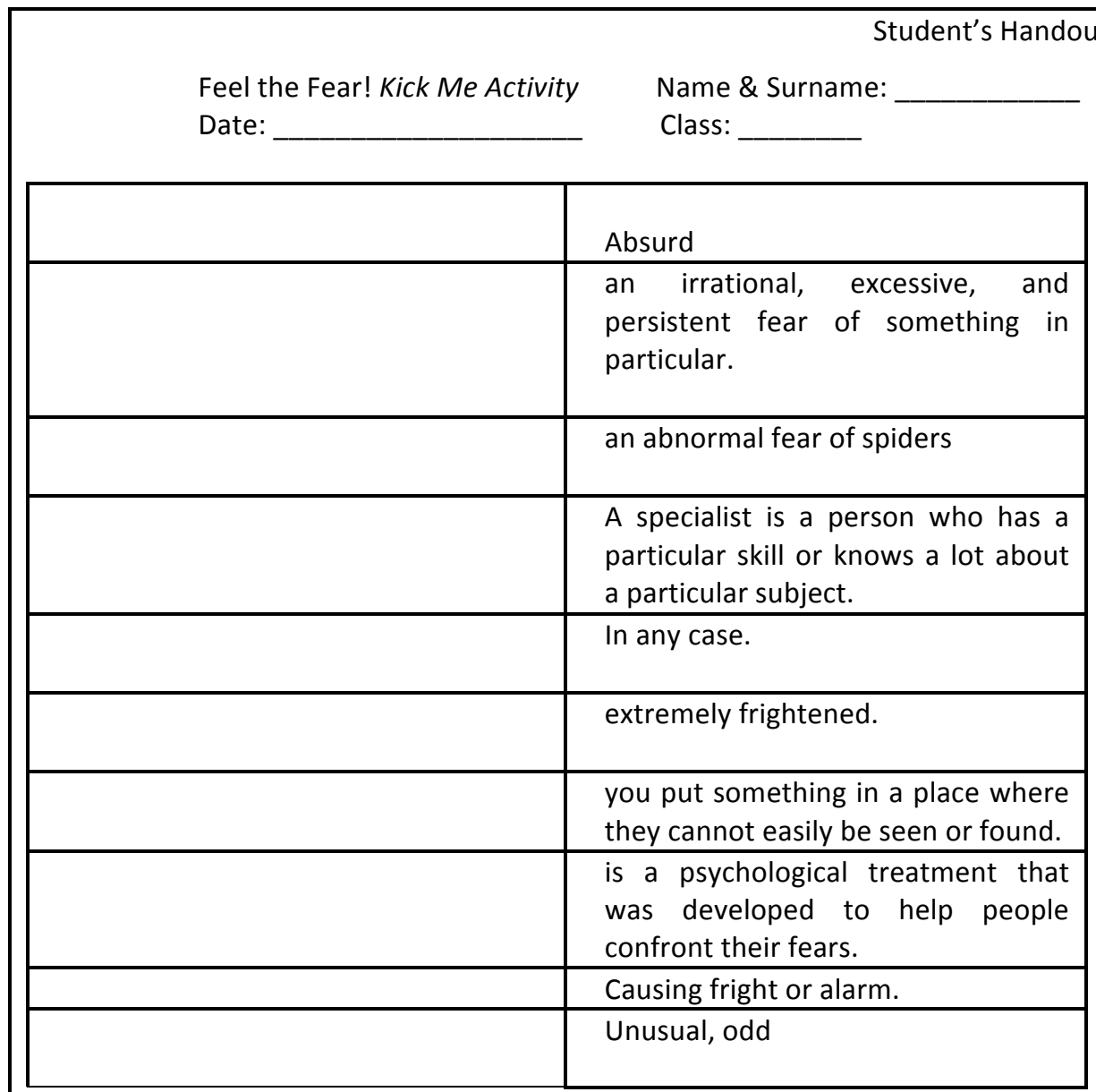

This activity consists of the following rules:

- Nobody gets kicked during this activity!

- Find the answers for your worksheet on the backs of your classmates.

- When you have them all, sit down at your desk, so that others can still see your label. 
Table 5. Teacher's Handout

\begin{tabular}{|c|c|}
\hline \multirow[b]{2}{*}{$\begin{array}{l}\text { Feel the Fear }{ }^{4} ! \text { Kick Me Activity } \\
\text { Date: }\end{array}$} & \multirow{2}{*}{$\begin{array}{l}\text { Teacher's Handout } \\
\text { Name \& Surname: } \\
\text { Class: }\end{array}$} \\
\hline & \\
\hline Ridiculous & \multirow{3}{*}{$\begin{array}{l}\text { Absurd } \\
\text { an irrational, excessive, and } \\
\text { persistent fear of something in } \\
\text { particular. }\end{array}$} \\
\hline & \\
\hline Phobia & \\
\hline Arachnophobia & an abnormal fear of spiders \\
\hline Specialist & $\begin{array}{l}\text { A specialist is a person who has a } \\
\text { particular skill or knows a lot about } \\
\text { a particular subject. }\end{array}$ \\
\hline Anyway & In any case. \\
\hline Terrified & extremely frightened. \\
\hline Hide (Hid) & $\begin{array}{l}\text { you put something in a place where } \\
\text { they cannot easily be seen or found. }\end{array}$ \\
\hline Exposure Therapy & $\begin{array}{l}\text { is a psychological treatment that } \\
\text { was developed to help people } \\
\text { confront their fears. }\end{array}$ \\
\hline Scary & Causing fright or alarm. \\
\hline Strange & Unusual, odd \\
\hline
\end{tabular}

The teacher gives the students ten minutes to finish their task matching 10 words with their appropriate definition (Table 4.). When the time finishes, the teacher says: "Time is up! ", and the students have to sit down. After that, the teacher checks out aloud who did it right, and corrects the errors. When implementing this activity, teachers have to take into account several criteria such as:

- Considering not only the students' level of English but other factors too, such as: motivation, amount of previous knowledge, social situation, geographic location, cultural level, genetic features (some have an innate intelligence - predisposition to learn new languages), age, etc.

- Time is a crucial factor. This activity cannot last more than ten minutes, as the students lose concentration, interest, etc.

- Number of students (amount). Within a large class the activity works better (15- 30 students).

- The classroom environment in general - affective relationship that is established between teacher and students, and the peer relationship.

\footnotetext{
${ }^{4}$ The didactic Unit that we were working that time, according to the text book was called Feel the Fear- that is the reason of why using these handouts.
} 


\section{Results}

To carry out this research we focused on the understanding and the attitudes of students, and what they actually learnt during this activity. To observe what positive and negative outcomes come from the adoption of a game in vocabulary acquisition, it is essential to examine the following factors: the students' responses, engagement, and achievement.

Table 6. Student reaction

\begin{tabular}{|l|}
\hline Student reaction \\
\\
\\
\hline Class A, B: $40 \%$ \\
Class C, E: $73 \%$ \\
Class D: $88 \%$ \\
\hline
\end{tabular}

Regarding the students' reactions towards the activity, there were different types of responses depending on their class, mood and interests. Firstly, in the classes C, E, we observed that their reactions were quite normal, even though they seemed somewhat excited at the beginning of the activity. Secondly, in class A, B, students were not enthusiastic at all, perhaps because they were not interested in the theme, or perhaps they felt somewhat lethargic (it was Friday). Thirdly, in class $D$, most of the learners (15 out of 17) were very interested and curious about "Kick Me Activity» and tried their best. They seemed to be perseverant with finding the answers while a relaxed atmosphere fostered the competitiveness in the classroom.

Table 7. Students' participation

\begin{tabular}{|l|}
\hline \multicolumn{1}{|c|}{ Students' participation } \\
\hline $\begin{array}{l}\text { Class A, B: } 50 \% \\
\text { Class C, E: } 87 \% \\
\text { Class D: } 94 \%\end{array}$ \\
\hline
\end{tabular}

In this part of the study, it is important to consider the students' positive or negative participation in the activity. This task provided an alternative to represent the students' level of engagement, ontask response and peer interaction. For example, these responses could be reproaches regarding the activity, or positive remarks about doing similar activities in other classes. We calculated the percentage of their positive and negative comments regarding the task. The result was that in class $D$ most of the research students $(70 \%)$ 
thought that during the task they participated more, as they did not feel any pressure from the teacher side. We would say that the students actively engaged in this activity, even the shy ones.

By contrast, in class A, B, some of the students did not participate the way we expected. They tended to speak in Spanish about unrelated topics. For example, when we were approaching some of them, they were talking about soccer. Additionally, in class C, E, students had a tendency to take more risks than in other classes, which, in a sense, helped them perform the task and be more participative.

We would say that, based on the research data, the students participation was overall good. We realized that we had more interaction with the students on the days that we did these types of activities, which may indicate their preferences for these types of tasks. What really surprised us was the participation of a student, who during the observation period was very distracted; however, in the end, this student's response to the task was amazing and collaborative.

Table 8. Student achievement

\begin{tabular}{|l|}
\hline \multicolumn{1}{|c|}{ Student achievement } \\
\hline \\
\hline $\begin{array}{l}\text { Class A, B: } 60 \% \\
\text { Class C, E: } 80 \% \\
\text { Class D: } 88 \%\end{array}$ \\
\hline
\end{tabular}

Regarding the students' accomplishment, the "Kick Me Activity», apart from providing fun, a relaxed atmosphere and curiosity, also developed the academic performance, and this was reflected in the final written exam. In this exam, there were different sections; however, we would say that around $85 \%$ of students were successful in the vocabulary section.

To collect results, both quantitatively and qualitatively, we worked with the students' survey answers, and we kept an observation journal to monitor their involvement in vocabulary activities. In the journal, we recorded various comments made by the students regarding the "Kick Me Activity». For example: «Me gustó mucho el juego», "me encantó», "¿lo podemos hacer de nuevo?». During the days that followed they kept asking us if we were going to do it again.

\section{Discussion and conclusions}

Throughout this activity, students interacted with each other, and also learnt new words from each other. Regarding the 
effectiveness of "Kick Me Activity", we can report that students seemed to learn new vocabulary. This game encourages vocabulary development and free expression, but it can also be used for vocabulary revision at the end of a unit.

This method is well suited for students with a lowerintermediate to advanced level, because they can formulate more extensive definitions; hence, helping themselves with their accumulated vocabulary. It is important to take into consideration that the study we made was limited as to the student groups, age, and time factors.

In summary, the "Kick Me Activity» makes the process of assimilation of new words more interactive and fun. Therefore, this task has become a tool of communication and discovery, and has created a more dynamic and participative atmosphere, as the activity is challenging and encourages the students' intuition and teamwork. However, the "Kick Me Activity" also presents several disadvantages; for instance, students might speak among each other about other things in their mother tongue, which creates minor chaos in the class.

In consequence, «increasing vocabulary knowledge is a basic part of the education process, both, as a means and as an end", declared the American linguist Nagy William. Vocabulary knowledge is achieved not only at school, but at home, by different means, such as watching movies or English programs, by interaction with native people, etc. Hence, there are many factors that foster the improvement of vocabulary. The present study tried to find and solve some of the problems that teachers and students face in the classroom regarding vocabulary knowledge.

It can be said that, according to these results, interaction, dynamic, cooperative games are the best way to teach and improve vocabulary in a Spanish context. This research showed the effects of learning tools, such as the Vocabulary Box, Kick Me Activity, and the Vocabulary Survey on 2 ESO students, with the objective of finding out whether the method of learning new words influenced the students' learning process. These procedures led to significant changes in achievement scores, and the data collection instruments showed that students selected the Vocabulary Box as their first choice, and the Kick Me Activity as a second option. The results were obtained by using the final written test, through the observation of students, and the survey taken.

Gunn Tim claimed that: "Few activities are as delightful as learning new vocabulary». This empirical research points out a set of interesting findings, of which the most relevant are related to the interaction of students with different dynamic and stimulating tasks, that encourage not only collaboration, entertainment and responsibility, but also the knowledge of vocabulary. 
VII. References

American Psycological Association. 2015. "What is Exposure Therapy?». Accessed June 1, 2015. https://www.apa.org/ptsdguideline/patients-and-families/exposure-therapy.

Amy, Bailey, Gina and Lori. 2012. "Let's Talk About Vocabulary Strategies». Concord, NC: Cox Mill High School. Accessed on May 10 , 2015 , https://literacy.uncc.edu/sites/literacy.uncc.edu/files/media/do cs/Let's\%20Talk\%20About\%20Vocabulary\%20Strategies\%20pres entation.pptx.

Byrne, Donn. 1976. Teaching Oral English. Longman Print. Essex.

Collins Dictionary, s.v. «anyway», accessed June 1, 2015, https://www.collinsdictionary.com/es/diccionario/ingles/anywa $\mathrm{y}$.

Collins Dictionary, s.v. "arachnophobia», accessed June 1, 2015, https://www.collinsdictionary.com/dictionary/english/arachnop hobia.

Collins Dictionary, s.v. «hide», accessed June 1, 2015, https://www.collinsdictionary.com/dictionary/english/hide.

Collins Dictionary, s.v. «phobia», accessed June 1, 2015, https://www.collinsdictionary.com/dictionary/english/phobia_1.

Collins Dictionary, s.v. «ridiculous», accessed June 1, 2015, https://www.collinsdictionary.com/dictionary/english/ridiculous

Collins Dictionary, s.v. "scary», accessed June 1, 2015, https://www.collinsdictionary.com/es/diccionario/ingles/scary.

Collins Dictionary, s.v. "specialist», accessed June 1, 2015, https://www.collinsdictionary.com/dictionary/english/specialist.

Collins Dictionary, s.v. "terrified», accessed June 1, 2015, https://www.collinsdictionary.com/dictionary/english/terrified.

Gunn, Tim. 2007. A Guide to Quality, Taste \& Style. New York: Abrams Image.

Harmer, Jeremy. 1983 The Practice of English Language Teaching. Essex: Longman Print.

Kumar, Rita and Robin Lightner. 2007. "Games as an Interactive Classroom technique: Perceptions of Corporate Trainers, College Instructors and Students». International Journal of Teaching and Learning in Higher Education 19 (1): 53-63. 
Mackay, Molly. 2007. Vocabulary Development. Activities and Games for Early Learners. Hunington Beach: Teacher Created Materials.

Merriam-Webster Dictionary, n.d. "a picture is worth a thousand words», accessed May 27, 2015, https://www.merriamwebster.com/dictionary/a\%20picture\%20is\%20worth\%20a\%20t housand\%20words.

Nagy, William. 1988. Teaching Vocabulary to Improve Reading Comprehension. Newmark: International Reading Association.

Oxford Dictionary, n.d. "game», accessed May 20, 2015, https://en.oxforddictionaries.com/definition/game.

Schmitt, Norbert and Michael McCarthy. 1997. Vocabulary: Description, Acquisition and Pedagogy. Cambridge, UK: Cambridge University Press.

Sorayaie, Ali. 2012. "The Effect of Games on EFL Learners' Vocabulary Learning Strategies». International Journal of Basic and Applied Science 1 (2): 252-256.

Thanh Huyen, Nguyen Thi and Khuat Thi Thu Nga. 2003. «Learning Vocabulary Through Games: The Effectiveness of Learning Vocabulary Through Games». The Asian EFL Journal 5 (4): 1-15.

Thornbury, Scott. 2002. How to Teach Vocabulary. Essex: Longman Print.

Walters State. 2015. "Lesson in a Box: Discipline Specific Vocabulary». Walters State. The Great Smoky Mountain Community College. Accessed on June 11, 2015. http://library.ws.edu/c.php?g=401199\&p=2728615. 